\title{
BRANQUITUDE NO ENSINO SUPERIOR: A PESQUISA SOBRE O BRANCO NAS RELAÇÕES ÉTNICO-RACIAIS
}

\author{
RESEARCH ON WHITE IN ETHNIC-RACIAL RELATIONS
}

\author{
Deivison Moacir Cezar de Campos1 \\ [https://orcid.org/0000-0001-9928-9825] \\ Tiago Soares Marques2 \\ [https://orcid.org/0000-0002-1881-7559] \\ DOI: 10.30612/raido.v15i37.14420
}

\begin{abstract}
RESUMO: O presente artigo trata de uma revisăo bibliográfica de teses sobre branquitude no ensino produzidas no Brasil nesta década, buscando analisar as abordagens e os diálogos possíveis entre elas. A pesquisa mostra como tem sido pensada a branquitude brasileira e quais as perspectivas para uma educaçâo mais igualitária.Para otensionamento teórico, foramutilizados os conceitos debranquitude (SCHUCMAN, 2012), racial literacy (TWINE, 2006) e colonialidade (QUIJANO, 2009). Foram analisadas cinco teses de doutorado, a partir de um estudo documental, utilizando como categorias objetivos, metodologia e aportes teóricos de cada autor. Os resultados mostram que o conceito de branquitude é proposto de maneira distinta entre os pesquisadores, sendo que alguns realizam uma diferenciaçâo do conceito de branquidade. De modo geral, todos entendem que é possível os sujeitos brancos se tornarem críticos e conscientes de sua condiçăo racial e apontam para a (re)educaçáo como o meio mais eficaz para a compreensâo da realidade e da possibilidade de combate às desigualdades.
\end{abstract}

Palavras-chave: branquitude; branquidade; racismo; educaçăo das relaçôes étnico-raciais; colonialidade.

ABSTRACT: This paper deals with a bibliographic review of theses on whiteness in teaching produced in Brazil in this decade, seeking to analyze the possible approaches and dialogues between them. The research shows how Brazilian whiteness has been thought about and what are the perspectives for a more equal education. For theoretical tensioning, the concepts of whiteness (SCHUCMAN, 2012), racial literacy (TWINE, 2006) and coloniality (QUIJANO, 2009) were used. Five doctoral theses were analyzed, based on a documentary study, using as categories objective objectives, methodology and theoretical contributions of each author. The results show that the

1 Universidade Luterana do Brasil, Canoas/RS. Doutor em Ciências da Comunicaçăo. Professor do PPG em Educaçăo e dos cursos de Comunicaçăo. E-mail: deivisondecampos@gmail.com

2 Universidade Luterana do Brasil, Canoas/RS. Mestrando em Educaçăo e pesquisador do NEABI/Ulbra. E-mail: tiago-sm97@gmail.com 
concept of whiteness is proposed differently among researchers, with some making differentiation from the concept of whiteness. In general, everyone understands that it is possible for white subjects to become critical and aware of their racial condition and point to (re) education as the most effective means for understanding reality and the possibility of combating inequalities.

Keywords: whiteness; racism; ethnic-racial relations education; coloniality

\section{INTRODUÇÃO}

Este artigo realiza uma revisăo bibliográfica de teses desenvolvidas no Brasil sobre branquitude e educaçâo, buscando analisá-las a fim de discutir suas abordagens e os diálogos possíveis entre elas. Os estudos sobre relaçôes étnico-raciais já possuem uma tradiçấo no Brasil, porém, foram discutidos em sua maioria a partir da perspectiva do lugar social do negro e de forma mais efetiva há algumas décadas sobre os indígenas. No entanto, os indivíduos identificados como brancos năo vinham sendo objeto de pesquisa, denotando uma normalizaçâo do sentido de homem como branco.

A partir da base do Banco de Teses e Dissertaçôes da Capes, foram identificadas cinco teses de doutorado e sete dissertaçôes de mestrado sobre branquitude nos diferentes níveis de ensino. Das doze produçôes, oito tratam do tema no ensino superior e quatro na educaçấo básica. Neste primeiro movimento de pesquisa sâo acionadas as cinco teses.

As teses analisadas compôem três áreas de conhecimento, sendo duas da Educaçāo, duas das Ciências Sociais e uma do Serviço Social, tendo como propostas observar, de modo geral, a inserçâo das identidades brancas no meio acadêmico brasileiro. Todas foram defendidas na década de 2010 e têm como base os estudos críticos da branquitude, mostrando a incipiência contemporânea da discussăo.

Os estudos sobre a identidade branca têm seu início, no Brasil, com Alberto Guerreiro Ramos, em A patologia social do 'branco' brasileiro, no ano de 1957. Porém, é na década de 1990, nos Estados Unidos, que se institucionalizam os estudos críticos da branquitude, com destaque para Ruth Frankenberg (JESUS, 2014). No Brasil, o debate foi retomado com a defesa das teses de doutorado por Edith Piza (1995) e de Maria Aparecida Bento (2002). O artigo Branco no Brasil? Ninguém sabe, ninguém viu, de Edith Piza, publicado em 2000, fomentou o crescimento dos estudos, ocorridos na última década. No entanto, o livro Psicologia social do racismo: estudos sobre branquitude e branqueamento no Brasil, organizado por Bento e Carone (2002) tornou-se a principal referência para o debate posterior. Desde entăo, diversos autores realizaram suas pesquisas sob essa perspectiva, como Lia Vainer Schucman, Liv Sovik, Lourenço Cardoso e Lúcio Otávio Alves de Oliveira - estes dois últimos já inserindo em suas análises a branquitude no contexto acadêmico e educacional.

O método utilizado para a análise é o da pesquisa bibliográfica (GIL, 2002), considerando a mesma de fundamental importância para futuras pesquisas sobre o tema. Sendo assim, através da revisâo de bibliografia, o artigo se propóe a indicar os caminhos que estăo sendo seguidos sobre a temática em questâo. Para o tensionamento do material empírico, foram utilizados os conceitos de branquitude (SCHUCMAN, 2012), racial literacy (TWINE, 2006) e colonialidade (QUIJANO, 2009). 
Esse texto relaciona-se a uma pesquisa mais abrangente sobre o debate do ensino das relaçóes étnico-raciais na formaçăo de professores de História. O tema tem sido debatido nos últimos anos principalmente depois da sançâo da lei 10.639/2003 que prevê a obrigatoriedade do ensino de história e cultura afro-brasileira em todos os níveis de ensino. Esse debate gira, principalmente, em torno da qualificaçăo necessária para valorizar a diversidade, de maneira que se entenda e respeite os aspectos sociais, históricos e culturais que envolvem a populaçăo brasileira. Apesar de haver diferentes movimentos de formaçâo de professores para a questâo étnico-racial, os estudos sobre a branquitude ainda năo estăo institucionalizados no campo histórico - como mostra o levantamento.

\section{O BRANCO COMO PADRÃO E NORMA NA EDUCAÇÃO}

No âmbito da educaçăo, as instituiçôes nem sempre consideraram importante pensar nas questōes étnico-raciais como forma de combater as desigualdades. Longe disso, o sistema educacional brasileiro no período pós-aboliçăo consagrou as relaçôes raciais existentes, baseada no mito da democracia racial, até os dias atuais. Segundo Jerry Dávila:

Na primeira metade do século XX, o pensamento racial ocupou papéis explícitos e implícitos na elaboraçăo da educaçăo pública. Um número restrito de cientistas, intelectuais e médicos dominava as decisôes sobre a educaçăo, e as práticas que criaram refletiram e reproduziram as desigualdades vigentes em sua sociedade (DÁVILA, 2006, p. 14).

Com a responsabilidade de construir um Brasil mais europeu com um senso de modernidade ligado à brancura, os educadores brasileiros estabeleceram normas racializadas, através da açăo e da prática que concedia ou negava recompensas com base nessas normas (DÁVILA, 2006). Percebe-se que, na tentativa de consolidar um pensamento único entre a populaçăo, a educaçáo foi usada como ferramenta, através da crença de que era preciso branquear a populaçăo. A ideia de embranquecimento se deve ao fato de que neste período o país era considerado uma naçăo inferior, por ter a maioria da populaçăo negra.

Desse modo, a educaçăo foi um instrumento eficaz para delimitar os espaços dos diferentes sujeitos na sociedade, a partir do critério racial, guardando o imaginário racista e discriminatório que persiste atualmente no Brasil. Segundo Dávila (2006, p. 36), "como a educaçâo é uma área de políticas públicas, revela as formas pelas quais os pensadores raciais colocaram suas ideias e hipóteses em prática". A partir disso entende-se que a educaçăo, enquanto agente de transformaçóes sociais, do mesmo modo que auxiliou no processo de construçâo do racismo, tem a capacidade de proporcionar aos sujeitos maior percepçáo sobre seus contextos e instigar a um pensamento crítico e reflexivo.

Nesta perspectiva, é importante que os estabelecimentos de ensino contem com instalaçôes e equipamentos sólidos e atualizados, bem como professores capacitados e comprometidos com a educaçăo de negros e brancos, corrigindo posturas, atitudes e palavras discriminatórias, para que assim possam se relacionar com respeito (BRASIL, 2004). Educar "negros e brancos" significa pensar discursos e práticas que envolvam ambas as populaçóes. 
Neste contexto, o lugar do branco na educaçăo para as relaçóes étnico-raciais tem sido discutido a partir do conceito de branquitude. Analisado por pesquisadores como Iray Carone e Maria Aparecida Silva Bento (2002), Adevanir Aparecida Pinheiro (2011), Lia Vainer Schucman (2012), Lourenço da Conceiçăo Cardoso (2014), entre outros, o conceito de branquitude pode ser definido como

[...] uma posiçăo em que sujeitos que ocupam esta posiçăo foram sistematicamente privilegiados no que diz respeito ao acesso a recursos materiais e simbólicos, gerados inicialmente pelo colonialismo e pelo imperialismo, e que se mantêm e săo preservados na contemporaneidade (SCHUCMAN, 2012, p. 23).

Interessante pensar este conceito como uma condiçăo de privilégio permanente pelo qual um grupo se mantém no poder em detrimento de outro. A branquitude pode ser considerada uma forma de perpetuaçáo do racismo, por naturalizar os lugares sociais historicamente construídos; ou seja, combater o racismo significa também enfrentar todas as formas, sejam elas simbólicas ou materiais, que privilegiem os brancos.

Nesse sentido, entende-se que a luta contra a branquitude, enquanto relaçáo de poder, náo deva ser desempenhada somente pelos negros. Ao contrário, cada vez mais os brancos devem se entender como tal e compreender que ser branco nâo é a norma, mas sim um lugar construído histórico e socialmente. Ser branco é também pertencer a uma condiçăo étnico-racial. Năo refletir sobre o papel do branco nas desigualdades raciais é uma maneira de persistir no pensamento de que constituem um problema exclusivamente do negro (BENTO, 2002).

Pensar a branquitude no contexto educacional, portanto, significa entender que o desafio da educaçăo étnico-racial necessita de uma ética que auxilie tanto a populaçâo negra, quanto a populaçáo branca a encontrar a melhor forma de interagir nesta reeducaçăo inclusiva do diferente, atuando em sociedade a partir de uma educaçăo social e racial enquanto sujeito e nâo apenas como objeto da globalizaçăo tecnológica brasileira (PINHEIRO, 2011). Diante disso, foram analisadas cinco teses que trabalham o conceito de branquitude na Educaçăo, sendo elas: "Identidade étnico-racial e universidade" (PINHEIRO, 2011) e "O branco ante a rebeldia do desejo" (CARDOSO, 2014), ambos da Ciências Sociais; "Branquitude em Foco" (LABORNE, 2014) e "Representaçóes acerca das identidades brancas no currículo de um curso de Licenciatura em História do Paraná" (SILVA, 2018), ambos da Educaçăo; e "Um estudo sobre branquitude no contexto de reconfiguraçăo das relaçōes raciais no Brasil", 2003-2013 (PASSOS, 2013), do Serviço Social. O conjunto de teses constitui o observável da presente reflexăo.

\section{O BRANCO NO CENTRO DO DEBATE ÉTNICO-RACIAL}

As teses analisadas pretendem, de modo geral, trazer o branco para a discussáo das relaçôes étnico-raciais. Mais do que buscá-lo para deixá-lo à margem, têm o intuito de fazer o branco se perceber enquanto uma construçáo social. Têm relevância no sentido de tornar o branco o centro da discussáo, năo como a referência, mas como aquele que produziu e ainda produz danos materiais e simbólicos à populaçăo negra e ao conjunto social, o que prejudica a si mesmo em consequência. 
Adevanir Aparecida Pinheiro, na tese Identidade étnico-racial e universidade: a dinâmica da visibilidade da temática afrodescendente e as implicaçōes eurodescendentes, em três instituiçôes de ensino superior no sul do país, defendida em 2011 no Programa de Pós-Graduaçáo em Ciências Sociais da Universidade do Vale do Rio dos Sinos (RS), analisa três universidades, pertencentes aos três estados do sul - Paraná, Santa Catarina e Rio Grande do Sul - com o objetivo de revisar os processos de inclusâo e exclusăo da populaçăo negra nesses espaços, a partir do estudo dos programas acadêmicos, projetos sociais, documentos institucionais e entrevistas.

A partir de um tripé metodológico, composto pela análise de discurso, estudo comparativo e dialética, a autora busca identificar os sinais concretos que mostram que as universidades estâo contribuindo para mudar a realidade social. Tendo como três principais teóricos Florestan Fernandes, Alberto Melucci e Paulo Freire, ela conclui que o discurso na sociedade brasileira tende à persistência da branquidade ${ }^{3}$ reproduzindo sua visăo de forma ampla, velada e convincente, através de discursos racistas discretos, conscientes ou năo. Nas três universidades percebe-se a inconsciência dos sujeitos brancos sobre a sua dominaçăo pelo racismo, mesmo que em níveis distintos.

Ana Helena Passos, em sua tese Um estudo sobre branquitude no contexto de reconfiguraçâo das relaçôes raciais no Brasil, 2003-2013, defendida em 2013 no Programa de Pós-Graduaçáo em Serviço Social da Pontifícia Universidade Católica do Rio de Janeiro, busca compreender o processo de (re)construçăo das identidades dos sujeitos brancos em um espaço onde há o imaginário de que brancos e negros estâo em uma mesma condiçâo política e social. A pesquisadora, através de entrevistas com indivíduos considerados da classe $\mathrm{C}$, de uma disciplina de História e Cultura Afro-Brasileira em uma Instituiçấo de Ensino Superior da cidade de Sáo Paulo, numa perspectiva teórica da racial literacy - letramento racial, analisa a fala desses sujeitos brancos sobre sua condiçăo e percepçóes referente às relaçôes étnico-raciais. A hipótese é que os discursos da mestiçagem e da democracia racial impedem que esses sujeitos tenham uma real consciência racial. A autora pretende mostrar que năo há uma compreensâo que possibilite aos sujeitos brancos se perceberem como portadores de privilégios. Nesse sentido, para ela, a passagem das marcas do fenótipo para as da identidade se dá através de uma trajetória política, proporcionada pela racial literacy, que é "a condiçấo de um aprendizado a partir de práticas sociais e da pertença sociocultural do sujeito que aprende" (PASSOS, 2013, p. 17).

Na tese $O$ branco ante a rebeldia do desejo: um estudo sobre a branquitude no Brasil, defendida em 2014 no Programa de Pós-Graduaçăo em Ciências Sociais da Universidade Estadual Paulista, Lourenço Cardoso procura investigar o que leva os pesquisadores brancos a dedicarem seus estudos e pesquisas sobre o negro. Porque o branco se interessa mais em pensar no Outro, e năo em si? Para ele, a branquitude pode ser percebida justamente nessa insistência do pesquisador branco ter o negro como objeto. Entrevistando doze pesquisadores brancos que estudam o negro e quatro pesquisadores brancos que estudam o branco, o autor constata que, sobre o problema

3 Pinheiro (2011) faz uma distinçăo entre os conceitos branquitude e branquidade. O primeiro seria a situaçăo dos brancos que têm atitudes explícitas no processo de relaçăo étnico-racial, já o segundo representa aqueles sujeitos brancos que estâo alheios a essa problemática. 
racial, o primeiro grupo considera que é um "problema do negro", enquanto o segundo acredita ser um "problema do branco". Nesse sentido, o autor também aponta para o fato de que sujeitos brancos como os entrevistados, que têm estudo e consciência sobre a realidade social, se enxergam dentro desse sistema, mas năo se observam e se autocriticam, que é o caso dos doze pesquisadores que estudam o negro.

Defendendo em 2014 no Programa de Pós-Graduaçâo em Educaçăo, Conhecimento e Inclusăo Social da Universidade Federal de Minas Gerais, a tese Branquitude em Foco: análises sobre a construçāo da identidade branca de intelectuais no Brasil, Ana Amélia Laborne busca compreender as percepçóes de pesquisadoras e pesquisadores classificados como brancos sobre o significado de ser branco no Brasil e sua relaçấo com a produçáo do conhecimento sobre as relaçōes étnico-raciais no meio acadêmico. Trabalhando com os conceitos de branquitude, mestiçagem e ideal de branqueamento, ela articula os mesmos numa proposta de entender como eles estăo marcados na construçâo da identidade nacional brasileira. Através de entrevistas semiestruturadas com quatro pesquisadores, ela também aborda as relaçóes de poder baseadas na raça, investigando as expressóes das hierarquias e simetrias raciais nas ciências sociais e humanas, com foco na Educaçấo, trazendo à tona uma importante reflexâo sobre a racialidade inserida no universo acadêmico.

José Bonifácio Alves da Silva, em sua tese Representaçóes acerca das identidades brancas no currículo de um curso de Licenciatura em História do Paraná, defendida em 2018 no Programa de Pós-Graduaçáo em Educaçăo da Universidade Católica Dom Bosco (MS), investiga sobre como as representaçóes das identidades brancas em um currículo marcam um curso de licenciatura em História. Realizando uma análise sobre as emendas das disciplinas, o projeto pedagógico do curso (PPC), as observaçôes de aulas e as entrevistas semiestruturadas com docentes e discentes, o pesquisador pretende pensar a identidade com diferença e a diferença com identidade (SILVA, 2018). Ele realiza discussóes referenciando-se em uma articulaçăo entre os Estudos Culturais, os Estudos Pós-Coloniais, a Teoria Educacional Crítica Neomarxista, o Grupo Modernidade/Colonialidade, os Estudos Críticos da Branquidade, as perspectivas Pós-Críticas da Educaçăo, a interculturalidade crítica e o multiculturalismo crítico. Ele conclui que apesar de haver tentativas de ressignificar o currículo de História, ainda há uma hegemonia sobre as representaçôes das identidades brancas, formando sujeitos críticos, porém ainda eurocentrados e colonizados.

Diante do panorama da pesquisa sobre a branquitude no contexto educacional, o processo de análise dos trabalhos permitiu verificar confluências e divergências entre eles. A análise de material bibliográfico, por seu lado, permite ao pesquisador entender até onde outros investigadores têm chegado e seus esforços, os métodos utilizados, as dificuldades enfrentadas e o que pode ser ainda investigado (TRIVIN̂OS, 1987). Além disso, a principal vantagem da pesquisa bibliográfica está no fato de que permite ao investigador o acesso a uma série de fenômenos muito mais ampla do que se necessitasse pesquisar diretamente (GIL, 2002).

Inicialmente foi realizada uma pesquisa no Banco de Teses e Dissertaçóes da Capes. Após a identificaçăo das teses produzidas, foi criado um instrumento de pesquisa na forma de uma tabela na plataforma de planilhas do Google na qual cada pesquisa foi transformada em dados de análise a partir das categorias resumo, introduçâo, metodologia, análise, conclusâo e área de conhecimento. Após a finalizaçâo 
desta etapa, foi realizada uma leitura a partir dos dados de cada tese a partir das categorias, seguido da leitura das categorias em conjunto, o que permitiu uma aproximaçăo e divergências entre as pesquisas. Os aspectos definidos para a análise desses dados foram os objetivos, a metodologia e os aportes teóricos de cada autor.

\section{O BRANCO COMO OBJETO DE ANÁLISE}

O diálogo entre as cinco teses se dá na medida em que pretendem analisar as relaçóes étnico-raciais a partir de uma ótica que viabilize a compreensăo do papel dos sujeitos brancos no combate ao racismo. Porém, além dessa questăo mais visível, há também outras conexóes entre as pesquisas. Com relaçáo aos objetivos, pode-se perceber uma aproximaçăo entre Cardoso (2014) e Laborne (2014), pois ambos investigam sobre o sujeito branco e sua relaçâo com as suas escolhas acadêmicas, ou seja, como é ser um branco pesquisador das relaçóes étnico-raciais. Lourenço Cardoso (2014) quer entender por que sujeitos brancos decidem pesquisar o negro, sua cultura, seu universo, enquanto Ana Amélia Laborne (2014) busca compreender as experiências sociais e trajetórias dos entrevistados e a relaçâo com suas percepçôes sobre ser branco no Brasil e na produçáo de conhecimento. Nota-se certa complementaçáo entre os trabalhos, pois enquanto o primeiro realiza uma análise que busca entender os pensamentos dos pesquisadores brancos, o segundo pretende compreender esses pensamentos através das vivências desses sujeitos.

Pode-se encontrar também uma relaçâo entre as teses de Passos (2013) e Silva (2018), pois enquanto a primeira trabalha com a (re)construçăo das identidades brancas de sujeitos que fazem parte de uma disciplina de História e Cultura Afro-Brasileira, o segundo busca compreender sobre como o currículo de um curso de História é marcado pelas representaçóes das identidades brancas. Nesse sentido, pode-se entender que o processo de consciência racial, proposto em Ana Helena Passos, necessita de uma reestruturaçâo dos conceitos e práticas presentes dos contextos educacionais. Segundo as DCNs para a Educaçāo das Relaçôes Étnico-Raciais, é necessário se desfazer da mentalidade racista e discriminadora secular, superando o etnocentrismo europeu, reestruturando relaçóes étnico-raciais e sociais, desalienando processos pedagógicos (BRASIL, 2004). A tese de Pinheiro (2011) é a que, de certo modo, dialoga com todas as outras, pois seu objetivo é examinar como a educaçăo das relaçôes étnico-raciais está inserida na universidade, através de documentos oficiais e açôes sociais, tanto pelas instituiçōes como também por parte dos professores e alunos.

Sobre a metodologia, todas as pesquisas se utilizam de entrevistas para aprofundar suas análises a partir das falas dos sujeitos entrevistados. Segundo Laborne (2014), a entrevista possibilita uma maior aproximaçăo da complexidade de determinados fenômenos. Com exceçâo de Cardoso (2014), que definiu a sua entrevista como aberta, os outros quatro definiram-nas como semiestruturadas. Segundo Augusto Triviños (1987), a entrevista semiestruturada pode ser entendida como

[...] aquela que parte de certos questionamentos básicos, apoiados em teorias e hipóteses, que interessam à pesquisa, e que, em seguida, oferecem amplo campo de interrogativas, fruto de novas hipóteses que vâo surgindo à medida que se recebem as respostas do informante (p. 146). 
Um fator importante dos métodos é o critério de classificaçâo étnico-racial utilizado pelos pesquisadores para definirem quem seriam seus entrevistados. Enquanto Passos (2013), Cardoso (2014) e Silva (2018) consideraram importantes a autodeclaraçăo, seja branca ou negra, Laborne (2014) escolheu seus sujeitos tendo como referência a classificaçăo atribuída pelos NEABs ${ }^{4}$. Pinheiro (2011) năo determinou o critério de classificaçấo sobre seus entrevistados, mas ao tratar o conceito de identidade, analisa que nâo é algo estático e que o sujeito pode interpretá-la, ao mesmo tempo em que ela também está relacionada ao reconhecimento pelo outro.

A questâo da autodeclaraçâo e classificaçâo étnico-racial vem sendo amplamente debatida em meio a essa discussâo sobre educaçăo. Segundo Edmar José da Rocha e Fúlvia Rosemberg,

Extensa bibliografia [...] têm evidenciado que o sistema de classificaçăo racial no Brasil é complexo, ambíguo e fluido, resultante do processo sofisticado de combinaçấo de elementos da aparência: cor da pele, traços corporais (formato do nariz, lábios, tipo e cor de cabelo), origem regional (Rosemberg, Piza, 1998/1999) e social [...] (ROCHA; ROSEMBERG, 2007, p. 764).

Ou seja, a questăo da identidade étnico-racial é muito complexa na sociedade brasileira. É importante lembrar que, diferentemente dos Estados Unidos, por exemplo, no Brasil a classificaçâo racial nâo se dá a partir da origem do indivíduo, mas com base em marcadores de aparência (ROCHA; ROSEMBERG, 2007). Isto é, o fenótipo - o que é visível - define o modo como um sujeito é visto pela sociedade, e por ele mesmo.

Nilma Lino Gomes (2016) destaca que nenhuma identidade é construída no isolamento, mas é negociada durante a vida toda por meio do diálogo, parcialmente exterior, parcialmente interior, com os outros. Tanto a identidade pessoal, quanto a socialmente derivada, sâo formadas em diálogo aberto e que estas dependem de maneira vital das relaçôes com os outros (GOMES, 2016). A discussâo incide fortemente no debate da branquitude, pois há situaçōes em que, indivíduos que possuem a pele branca, mas com descendência negra, se autodeclaram negros, mas em determinados espaços săo privilegiados em detrimento de sujeitos negros. Essas questōes permeiam o modo como as pessoas se relacionam em sociedade.

O debate sobre essa relaçấo do pesquisador com o tema aparece na tese de Laborne (2014). Ao entrevistar quatro pesquisadores considerados brancos pelos NEABs, a pesquisadora constatou que nem todos concordaram com essa classificaçâo, sendo que um dos sujeitos se identificava como negro, enquanto outro náo concordava com classificaçōes raciais, se reconhecendo enquanto brasileiro. O que Laborne (2014) analisa a partir disso é que esses indivíduos constroem sua identidade pautados em elementos da branquitude, branqueamento e miscigenaçăo, permeados também por um discurso de nacionalidade que ignora os elementos raciais que compóem a formaçăo de uma identidade.

Outro aspecto relevante é que a brancura ${ }^{5}$ da pesquisadora, no caso de Passos

$4 \quad$ Núcleo de Estudos Afro-Brasileiros.

5 Há um debate crescente sobre as diferenças entre os termos brancura, branquitude e branquidade. 0 primeiro é normalmente utilizado para se referir ao fenótipo (PASSOS, 2013). Sobre o segundo e o 
(2013), facilitou a comunicaçâo e o diálogo com os entrevistados, por se sentirem mais "à vontade" para falarem determinadas questôes que năo conseguiriam para uma pessoa negra. Este fato se torna mais interessante e complexo se comparado com a tese de Lourenço Cardoso (2014) na qual ele entrevista pesquisadores brancos das relaçōes étnico-raciais. Quando questiona se ele fosse branco os entrevistados se sentiriam mais confortáveis, a maioria das respostas foi inversa. Ou seja, a maioria respondeu que nâo se sentiria mais confortável, muito devido ao fato de desconfiar de um pesquisador branco, duvidando das suas reais intençôes.

Considerando que na pesquisa de Passos (2013) os entrevistados sâo graduandos e na de Cardoso (2014) sâo pesquisadores consolidados, pode-se concluir que o "letramento racial" - já alcançado nos entrevistados de Cardoso - proporciona um entendimento sobre a realidade social. Os pesquisadores brancos năo enxergam no pesquisador negro uma barreira. Diante disso, pode-se considerar que o letramento racial estaria ligado a um projeto político de negociaçáo de identidades, a partir do prisma afro-educacional (PASSOS, 2013), entendendo que os pesquisadores brancos que pesquisam as relaçôes étnico-raciais já desenvolveram uma identidade que nâo exclui o outro.

\section{O BRANCO RESSIGNIFICADO}

Com relaçâo aos aportes teóricos e as análises, todos os autores se utilizam do conceito de branquitude, porém divergem entre si quanto a definiçăo dele, introduzindo também o conceito de branquidade. Para alguns pesquisadores, como, Pinheiro (2011) e Laborne (2014), a branquitude seria a condiçăo do branco que já alcançou uma consciência crítica e combate ao racismo. Já a branquidade seria o branco que năo tem essa consciência e que acredita ser superior. Passos (2013) e Cardoso (2014) utilizam o conceito branquitude sem distinguir de branquidade. Passos (2013) justifica essa indiferenciaçấo, relacionado com o conceito de negritude e por haver maior número de pesquisas que usam o conceito.

Cardoso (2014) acredita que essa distinçâo ainda precisa ser melhor formulada e que alguns pesquisadores brancos a fazem para criar uma divisăo hierárquica entre o branco consciente e náo consciente, sendo que ambos continuam sendo tratados da mesma maneira pela sociedade. Seguindo a lógica, Silva (2018) utiliza ambos os termos como sinônimos, por entender que mesmo os que já despertaram a consciência, năo tem um despertar pleno e que muitas vezes năo se percebem em situaçôes que sâo privilegiados. Porém, discorda de Cardoso (2014), que aponta para uma distinçáo entre branquitude crítica e acrítica.

Pinheiro (2011) e Laborne (2014) diferenciam os dois termos nas suas pesquisas, porém năo no mesmo sentido. Para Pinheiro (2011), a branquitude seria a situaçâo dos brancos que têm uma atitude explícita no processo de relaçăo étnico-racial, seja positiva ou negativa, enquanto a branquidade seriam aqueles sujeitos brancos que estâo alheios a qualquer problemática étnico-racial. Laborne (2014) utiliza o conceito de

terceiro ainda há debates (SILVA, 2018) sobre os seus significados e diferenças, que serăo explicados ao longo do texto. 
branquitude como uma possibilidade de consciência crítica e questionamento do lugar de privilegiado, enquanto branquidade como uma perspectiva única e exclusivamente racista. Independente das distinçōes que cada autor coloca, há em comum a todos a ideia de que existe a possibilidade de criar uma branquitude consciente e crítica.

Nesse sentido, o conceito de racial literacy é utilizado por Passos (2013) e Laborne (2014) como fundamental para que os sujeitos brancos tomem consciência da sua condiçâo enquanto privilegiados. Apesar dos outros autores nâo o utilizarem, a intençāo de todos é a mesma, demonstrar que é possível haver uma ressignificaçáo da branquitude. O conceito de racial literacy, de acordo com Passos (2013), foi desenvolvido por France Winddance Twine, que realizou uma pesquisa com 121 casais interraciais na Inglaterra e nos Estados Unidos, mostrando que o sujeito branco pode desenvolver um olhar crítico sobre o racismo e construir sua própria identidade. Para Twine,

\begin{abstract}
"Letramento racial" é um conjunto de práticas que pode ser melhor caracterizado como uma "prática de leitura" - uma forma de perceber e responder individualmente às tensóes das hierarquias raciais da estrutura social - que inclui o seguinte: (1) um reconhecimento do valor simbólico e material da branquitude; (2) a definiçăo do racismo como um problema social atual, em vez de um legado histórico; (3) um entendimento de que as identidades raciais săo aprendidas e um resultado de práticas sociais; (4) a posse de gramática e um vocabulário racial que facilita a discussáo de raça, racismo e antirracismo; (5) a capacidade de traduzir e interpretar os códigos e práticas racializadas de nossa sociedade e (6) uma análise das formas em que o racismo é médiado por desigualdades de classe, hierarquias de gênero e heteronormatividade (TWINE, 2006, p. 344 apud PASSOS, 2013, p. 83-84).
\end{abstract}

Considerando esse conceito como uma "prática de leitura", entende-se que essa transformaçáo no pensamento se dá a partir de novos olhares sobre a sociedade. Diante disso, a colonialidade do saber, referida por Laborne (2014) e Silva (2018), mas também mencionada por Passos (2013) e Cardoso (2014), ganha importância nesse debate.

A colonialidade é tratada como o modo com que as relaçôes herdadas do colonialismo persistem sob formas diferentes, sejam materiais ou simbólicas. Esse conceito é definido por Aníbal Quijano como

[...] um dos elementos constitutivos e específicos do padráo mundial do poder capitalista. Sustenta-se na imposiçăo de uma classificaçăo racial/étnica da populaçáo do mundo como pedra angular do referido padrăo de poder e opera em cada um dos planos, meios e dimensôes, materiais e subjectivos, da existência social quotidiana e da escala societal. Origina-se e mundializa-se a partir da América (QUIJANO, 2009, p. 73).

Ou seja, na prática năo há mais escravizaçăo, por exemplo, mas as relaçôes sociais ainda sâo marcadas pela raça, criando uma realidade que ainda inferioriza as populaçóes diferentes do que se convencionou como o padrăo de ser humano: 0 branco europeu. A colonialidade do saber, portanto, é uma herança do colonialismo e estabeleceu o eurocentrismo como a única forma de conhecer legítima, sendo utilizada como instrumento de dominação, deslegitimando aqueles conhecimentos năo europeus (SILVA, 2018). 
Laborne (2014) explica que a branquitude ocupa um lugar importante nessa discussăo, justamente por ser uma construçăo ideológica bem-sucedida do projeto modernista de colonizaçăo, que detêm o poder e define o eu e o outro, tornando-se instrumento de poder. O conceito pode ser bem observado na tese de Silva (2018) na qual ele mostra como um currículo de um curso de História é altamente centrado nos conhecimentos europeus. Nesse sentido, a tese de Lourenço Cardoso dialoga com a de Silva (2018), quando conclui, através das entrevistas que ser branco "significa possuir o monopólio da História e de sua perspectiva" (CARDOSO, 2014, p. 210).

Essa visada aponta que mesmo indivíduos que combatem as desigualdades também estâo propensos a práticas racistas, pois se omitir em determinadas situaçôes racistas é também contribuir para sua perpetuaçăo. Segundo Maria Aparecida Bento,

O silêncio, a omissăo, a distorçăo do lugar do branco na situaçăo das desigualdades raciais no Brasil têm um forte componente narcísico, de autopreservaçăo, porque vem acompanhado de um pesado investimento na colocaçáo desse grupo de referências da condiçăo humana (BENTO, 2002, p. 30).

A autora entende que o fato de náo querer legitimar o discurso que revela os privilégios sociais é comum entre aqueles sujeitos que se expressam contra o racismo e todas as suas consequências, năo sendo algo que existe apenas entre os que discriminam por preconceito. Segundo Bento (2002), há uma forte tendência por parte dos sujeitos brancos de discriminar a partir do interesse que têm em manter seus privilégios e tal fato pode estar ligado ou năo ao sentimento de rejeiçấo ao negro.

A interseccionalidade entre raça e classe é outro aspecto observado pelos autores. Na tese de Passos (2013), no discurso dos entrevistados, é possível verificar que devido ao fato desses sujeitos pertencerem a uma classe social subalterna, há um sentimento de igualdade com relaçăo aos negros, impossibilitando que eles percebam os privilégios materiais e simbólicos proporcionados por sua brancura. Ana Amélia Laborne (2014) também propóe esse debate, mostrando que mesmo pesquisadores que se dedicam à temática étnico-racial consideram que há uma sobreposiçăo da classe sobre a raça. Tentam com isso justificar os problemas da populaçăo negra através da explicaçăo que a maioria é pobre (LABORNE, 2014), desconsiderando os problemas inerentes ao aspecto racial. A pesquisa de Cardoso (2014) dialoga com as anteriores, inserindo o conceito de the white trash, utilizado para explicar o contexto norte-americano de sujeitos "brancos lixos", oriundos de uma mentalidade arcaica, baixo nível de escolaridade, condiçăo socioeconômica e leitura de mundo.

Outra questăo apontada por Passos (2013) é que quando o branco pobre começa a entender sobre privilégios é como se estivesse levantando um véu de cegueira. Nessa mesma direçấo, Edith Piza (2002) usa a metáfora da porta de vidro para explicar a descoberta racial pelos sujeitos brancos. Para ela, "bater contra uma porta de vidro aparentemente inexistente é um impacto fortíssimo e, depois do susto e da dor, a surpresa de náo ter percebido o contorno do vidro, a fechadura, os gongos de metal que mantinham a porta de vidro" (PIZA, 2002, p. 61). Portanto, o racismo nâo é praticado somente por aqueles sujeitos que têm aversáo ao negro e que se sentem superiores, pois esses indivíduos têm consciência do seu racismo. Se a percepçâo do racismo causa tanto impacto e surpresa é porque ele nâo é algo explícito, ou seja, é algo velado, 
que se esconde entre "piadas" e "brincadeiras inocentes".

O conjunto de estudos, portanto, mostra uma variedade de abordagens do debate, revelando que a branquitude pode ser um campo de pesquisa muito apropriado para aqueles que se interessam em buscar perspectivas complexas sobre as relaçóes étnico-raciais. É possível observar o diálogo existente na medida em que as teses dialogam no intuito de pensar como a branquitude se insere na educaçâo. A concentraçâo em áreas tradicionais da discussâo sobre identidade e diferença, Educaçăo, Ciências Sociais e Serviço Social, aponta também para a demanda que existe em discutir a branquitude a partir de outras áreas, deslocando o debate da perspectiva do outro sociológico para o considerado normal, o branco euroreferenciado.

\section{CONCLUSÃO}

O conceito de branquitude é proposto de maneira distinta nas cinco pesquisas, demonstrando uma abertura para estudos e debates sobre a definiçăo e operacionalizaçâo do mesmo. Também aponta para a necessidade de uma melhor discussáo sobre a distinçấo, ou sobreposiçâo dos conceitos de branquitude e branquidade - questăo ainda divergente entre os pesquisadores. De todo modo, todas as teses analisadas destacam que o entendimento da perspectiva permite aos sujeitos uma melhor compreensăo das desigualdades raciais.

A branquitude, de forma geral, para os pesquisadores, aponta para uma condiçăo de privilégio. Para alguns dos pesquisadores, isso se dá de forma consciente e, para outros, nâo há distinçâo entre os que se entendem e nâo nesta condiçâo. Em relaçâo ao conceito de branquidade, três das pesquisas consideram que nâo há diferenças entre os conceitos e que as definiçóes precisam de mais estudos e tensionamentos. Outros dois estudos percebem uma diferença conceitual, entendendo a branquitude como uma identidade branca positiva e crítica e a branquidade o seu oposto, ou seja, uma condiçăo de sujeito sem consciência racial.

A partir da análise das teses, entende-se que essas apontam para uma predominância, no meio acadêmico, de um pensamento colonizado e eurocentrado. As pesquisas auxiliam no processo de compreensâo sobre a realidade social, pois demonstram a importância que os sujeitos brancos têm no combate ao racismo. Entendendo a colonialidade como um elemento central na definiçăo dos espaços de poder e privilégio, os pesquisadores buscam inserir a branquitude nesse contexto, tentando entender como ela opera dentro do meio acadêmico.

Portanto, a Educaçăo é inserida nessa problemática por ser entendida pelos autores como uma questâo de grande importância para o aprofundamento da discussâo sobre as relaçóes étnico-raciais. Como eles apontam, é através da (re)educaçăo de pessoas brancas e negras que será possível construir uma sociedade mais justa, compreendendo a educaçăo das relaçôes étnico-raciais dentro de um processo de luta e resistência.

De forma geral, os autores consideram que a consciência racial é um instrumento que leva a resultados positivos na luta antirracista. Alguns deles se utilizam do conceito de racial literacy, que seria o letramento racial dos sujeitos brancos; ou seja, um processo que possibilita a esses indivíduos entenderem sua realidade e seus privilégios. 
Nesse sentido, os cinco pesquisadores acreditam que é possível haver a ressignificaçâo da identidade branca, buscando sujeitos brancos conscientes e críticos.

O debate sobre a temática da branquitude ainda exige maior aprofundamento. As pesquisas desenvolvidas até os dias atuais têm revelado o caráter central desse conceito, entendendo o mesmo como chave para a compreensăo da complexidade da discussâo étnico-racial. Através de diversos estudiosos da branquitude - um número crescente - é possível identificar de forma mais profunda os enredamentos e normalizaçáo do racismo na sociedade.

Essa pesquisa trouxe resultados positivos a sua proposta, pois mostra como a branquitude dentro do meio educacional e acadêmico vem sendo pensada e discutida, mostrando as diversas interpretaçôes a respeito do seu conceito. Também por propor uma reflexăo sobre as possibilidades de uma educaçấo igualitária, a partir da conscientizaçáo dos sujeitos brancos na luta contra o racismo. 


\section{REFERÊNCIAS}

BENTO, Maria Aparecida Silva. Pactos narcísicos no racismo: branquitude e poder nas organizaçōes empresariais e no poder público. 2002. Tese (Doutorado em Psicologia Escolar e do Desenvolvimento Humano) Universidade de Săo Paulo, Săo Paulo, 2002.

BRASIL. Conselho Nacional de Educaçăo. Diretrizes Curriculares Nacionais para a Educaçăo das Relaçôes Étnico-Raciais e para o Ensino de História e Cultura AfroBrasileira e Africana. Resoluçâo CNE/CP nº 1, de 17 de junho de 2004. Brasília, Diário Oficial [da] República Federativa do Brasil, 22 de junho de 2004, Seçăo 1, p. 11.

CARDOSO, Lourenço da Conceiçấo. 0 branco ante a rebeldia do desejo: um estudo sobre a branquitude no Brasil. 2014. Tese (Doutorado em Ciências Sociais) - Universidade Estadual Paulista, Săo Paulo, 2014.

CARONE, Iray; BENTO, Maria A. (Org.). Psicologia social do racismo - estudos sobre branquitude e branqueamento no Brasil. Petrópolis, RJ: Vozes, 2002.

DÁVILA, Jerry. Diploma de Brancura: política social e racial no Brasil - 1917-1945. São Paulo: Editora Unesp, 2006.

GIL, Antonio Carlos. Como Elaborar Projetos de Pesquisa. 4ed. Săo Paulo: Atlas, 2002. GOMES, Nilma Lino. Corpo e cabelo como símbolos da identidade negra. In: FIGUEIREDO, Angela; CRUZ, Cintia (Orgs.). Beleza negra: representaçôes sobre o cabelo, o corpo e a identidade das mulheres negras - Coleçâo UNIAFRO. Cruz das Almas: EDUFRB, 2016.

JESUS, Camila Moreira de. O Privilégio da Brancura na Escola Pública: uma etnografia no colégio estadual Edvaldo Brandăo Correia em Cachoeira-BA. 2014. Dissertaçăo (Mestrado em Ciência Sociais) - Universidade Federal do Recôncavo da Bahia, Cachoeira, 2014.

LABORNE, Ana Amélia de Paula. Branquitude em foco: análises sobre a construçăo da identidade branca de intelectuais no Brasil. 2014. Tese (Doutorado em Educaçăo) Universidade Federal de Minas Gerais, Belo Horizonte, 2014.

PASSOS, Ana Helena Ithamar. Um estudo sobre branquitude no contexto de reconfiguraçâo das relaçôes raciais no Brasil, 2003-2013. 2013. Tese (Doutorado em Serviço Social) - Pontifícia Universidade Católica do Rio de Janeiro, Rio de Janeiro, 2013.

PINHEIRO, Adevanir Aparecida. Identidade étnico-racial e universidade: a dinâmica da visibilidade da temática afrodescendente e implicaçôes eurodescendentes, em três instituiçōes do ensino superior no sul do país. 2011. Tese (Doutorado em Ciências Sociais) - Universidade do Vale do Rio dos Sinos, Săo Leopoldo, 2011.

PIZA, Edith Silveira Pompeu. 0 caminho das águas: estereótipos de personagens femininas negras na obra para jovens, de escritoras brancas. 1995. Tese (Doutorado em Psicologia Social) - Pontifícia Universidade Católica de São Paulo, São Paulo, 1995.

PIZA, Edith Silveira Pompeu. Porta de vidro: entrada para a branquitude. In: CARONE, Iray; BENTO, Maria A. (Org.). Psicologia social do racismo: estudos sobre branquitude e branqueamento no Brasil. Petrópolis, RJ: Vozes, 2002.

QUIJANO, Aníbal. Colonialidade do Poder e Classificaçâo Social. In: SANTOS, Boaventura de Sousa; MENESES, Maria Paula (Org.). Epistemologias do Sul. Coimbra: Almedina, 2009. 
ROCHA, Edmar J. da; ROSEMBERG, Fúlvia. Autodeclaraçáo de cor e/ou raça entre escolares paulistanos(as). Cadernos de Pesquisa, v. 37, n. 132, p. 759-799, set./dez. 2007.

SCHUCMAN, Lia Vainer. Entre o "encardido", o "branco" e o "branquíssimo": raça, hierarquia e poder na construçăo da branquitude paulistana. 2012. Tese (Doutorado em Psicologia Social) - Instituto de Psicologia da Universidade de Sáo Paulo, São Paulo, 2012.

SILVA, José Bonifácio Alves da. Representaçōes acerca das identidades brancas no currículo de um curso de Licenciatura em História do Paraná. 2018. Tese (Doutorado em Educaçăo) - Universidade Católica Dom Bosco, Campo Grande, 2018.

TRIVIN̂SO, Augusto Nibaldo Silva. Introduçáo à pesquisa em ciências sociais: a pesquisa qualitativa em educaçăo. Săo Paulo: Atlas, 1987.

TWINE, France Winddance. The Gap Between Whites and Whiteness. Interracial Intimacy and Racial Literacy. W.E.B Du Bois Institute for African and African American Research. 2006. p. 341-363. 